University of Nebraska - Lincoln

DigitalCommons@University of Nebraska - Lincoln

Agronomy \& Horticulture -- Faculty Publications

Agronomy and Horticulture Department

$11-15-2015$

\title{
Residue Harvest Effects on Irrigated, No-Till Corn Yield and Nitrogen Response
}

\author{
Charles S. Wortmann \\ University of Nebraska-Lincoln, cwortmann2@unl.edu \\ Charles A. Shapiro \\ University of Nebraska-Lincoln, cshapiro1@unl.edu \\ Marty R. Schmer \\ University of Nebraska-Lincoln, marty.schmer@ars.usda.gov
}

Follow this and additional works at: https://digitalcommons.unl.edu/agronomyfacpub

Part of the Agricultural Science Commons, Agriculture Commons, Agronomy and Crop Sciences Commons, Botany Commons, Horticulture Commons, Other Plant Sciences Commons, and the Plant Biology Commons

Wortmann, Charles S.; Shapiro, Charles A.; and Schmer, Marty R., "Residue Harvest Effects on Irrigated, No-Till Corn Yield and Nitrogen Response" (2015). Agronomy \& Horticulture -- Faculty Publications. 847. https://digitalcommons.unl.edu/agronomyfacpub/847

This Article is brought to you for free and open access by the Agronomy and Horticulture Department at DigitalCommons@University of Nebraska - Lincoln. It has been accepted for inclusion in Agronomy \& Horticulture -Faculty Publications by an authorized administrator of DigitalCommons@University of Nebraska - Lincoln. 


\title{
Residue Harvest Effects on Irrigated, No-Till Corn Yield and Nitrogen Response
}

\author{
Charles S. Wortmann,* Charles A. Shapiro, and Marty R. Schmer
}

\begin{abstract}
Crop residue harvest occurs on about $40 \%$ of Nebraska's 3,700,000 ha of corn (Zea mays L.) land, primarily for feeding of beef cattle. Immobilization of applied $\mathrm{N}$ is expected to be less with residue harvest due to reduced microbial activity for digestion of high $\mathrm{C} / \mathrm{N}$ ratio organic material. Residue reduction may affect subsequent crop yield and response to applied N. Field research was conducted at three locations over $2 \mathrm{yr}$ in eastern Nebraska for irrigated, no-till corn following corn to determine residue harvest effects on yield and the economically optimal nitrogen rate (EONR). Study sites had deep silt loam or silty clay loam soil with good water infiltration and plantavailable water holding capacity. Mean aboveground biomass $\mathrm{N}$ content, applied $\mathrm{N}$ recovery efficiency, and grain yield were 22, 43 , and $20 \%$ higher with $>75 \%$ residue removal compared with no residue removal. Agronomic efficiency of applied $\mathrm{N}$ use was not consistently affected. The residue removal effects were often greater in the third compared with second year of continuous corn. The residue removal effect on EONR was not consistent over site-years, and the mean reduction in EONR with residue removal was between 10 and $20 \mathrm{~kg} \mathrm{ha}^{-1}$.While removal of some corn residue is expected to result in higher yield of the following corn crop, reduction in applied $\mathrm{N}$ need cannot be well predicted before planting.
\end{abstract}

Published in Agron. J. 108:384-390 (2016)

doi:10.2134/agronj2015.0361

Received 29 July 2015

Accepted 26 Oct. 2015

Copyright (C) 2016 by the American Society of Agronomy 5585 Guilford Road, Madison, WI 53711 USA

All rights reserved

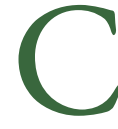
ORN CROP residue harvest by chopping silage, baling stover,or grazing occurs on about $40 \%$ of Nebraska's $3,700,000$ ha of corn land, primarily for feeding of beef (Klopfenstein et al., 2013) and may increase to meet future feedstock demands for ethanol production (Cantrell et al., 2014; Alternative Fuels Data Center, 2014; DuPont Cellulosic Ethanol. 2012; Biomass Research and Development Board, 2009). Corn residue harvest results in $\mathrm{N}$ removal of approximately $8.5 \mathrm{~kg} \mathrm{Mg}^{-1}$ (Wortmann et al., 2012). Immobilization of applied $\mathrm{N}$ is expected when much high $\mathrm{CN}$ crop residue remains in the field as is typical following corn grain harvest (Myrold and Bottomley, 2008). The CN of corn residue is typically between 60 and 70 . Reduced immobilization may more than compensate for $\mathrm{N}$ removed in residue harvest. When corn follows soybean in rotation, applied $\mathrm{N}$ requirement is typically 40 to $50 \mathrm{~kg} \mathrm{ha}^{-1}$ less compared to corn following corn and this is attributed at least partly to less $\mathrm{N}$ immobilization following soybean (Shapiro et al., 2009; Dobermann et al., 2011). While soybean fixes much atmospheric N, N removal in soybean grain harvest commonly exceeds fixed $\mathrm{N}$ and a net $\mathrm{N}$ contribution to the following crop is not expected (Salvagiotti et al., 2008). However, the quantity of soybean crop residue is much less compared with corn and the soybean leaf senescence and decomposition occurs earlier enough so that significant residue $\mathrm{N}$ release occurs before planting the following corn crop. Therefore, the potential for applied $\mathrm{N}$ immobilization is less with soybean compared with corn residue. The lower applied N required for corn when the previous crop is soybean compared with corn is attributed to this reduced potential for $\mathrm{N}$ immobilization by microbes involved in decomposition of crop residues.

Immobilization of $\mathrm{N}$ is expected to be less if corn crop residues are less. Therefore, applied $\mathrm{N}$ requirement for a following corn crop may be less if crop residues are reduced through harvest. Residue removal decreased the EONR by $>12$ and $>19 \mathrm{~kg} \mathrm{ha}^{-1}$ for no-till and strip till, respectively, in southern Minnesota (Sindelar et al., 2013). Schoessow et al. (2010) found that maximization of corn yield required

C.S. Wortmann and C.A. Shapiro, Dep. of Agronomy and Horticulture, Univ. of Nebraska-Lincoln, Lincoln, NE 68583-0915; and M.R. Schmer, Grain, Forage, and Bioenergy Research Unit, USDA-ARS, Univ. of Nebraska-Lincoln, Lincoln, NE 68583-0937. *Corresponding author (cwortmann2@unl.edu)..

Abbreviations: ARDC, Agriculture Research and Development Center; EONR, economically optimal nitrogen rate; HAL, Haskell Agricultural Laboratory; NAE, agronomic efficiency of applied nitrogen; NDVI, normalized difference vegetative index; NHI, nitrogen harvest index; NP, north pivot; NUp, nitrogen content of the aboveground biomass; NRE, recovery efficiency for applied nitrogen; NDRE, normalized difference red edge; SP, south pivot. 
41 to $134 \mathrm{~kg} \mathrm{ha}^{-1}$ less $\mathrm{N}$ with removal compared with no soybean residue removal for 3 site-years but there was no residue removal effect for 9 of the 12 site-years.

Crop residue harvest often affects the yield of the following crop but the direction of the effect depends on production conditions. Residue removal may worsen soil water deficits due to higher soil temperature and increased runoff. When soil water deficits are likely to occur, residue removal may therefore contribute to yield loss for the following crop (Linden et al., 2000; Wilhelm et al., 2004). Residue removal effects on soil temperature, and thereby on rate of crop development, have been well documented (Sindelar et al., 2013; Halvorson and Stewart, 2015). The interactions between tillage practice, $N$ requirement, and residue removal can be important (Sims et al., 1998). Continuous corn yield was similar for no-till and tilled with all crop residue removed but less with no-till where no residue was removed (Coulter and Nafziger, 2008). In a another study, however, crop residue removal resulted in corn yield increases of 6.5 and $9 \%$ for tillage and no-till, respectively (Sindelar et al., 2013). Averaged over 10 cropping seasons, irrigated corn grain yields were 7.5 to $8.6 \%$ higher for no-till when corn residue was removed compared with no residue removal, while grain yields were similar under tillage in all residue removal treatments (Schmer et al., 2014).

In an analysis of 239 site-years across 36 research sites that were primarily in the U.S. Corn Belt, Karlen et al. (2014) found mean corn yields of $9.8,10.1$, and $10.1 \mathrm{Mg} \mathrm{ha}^{-1}$ with no, moderate, and high rates of residue removal. This amounted to a $3 \%$ average yield increase with corn residue removal compared with no corn residue removal. Longitude, latitude, yield level, and previous crop of corn compared with soybean did not account for much variation in the residue removal effects on corn yield. Yield was on average $20 \%$ more with no residue removal for tilled compared with no-till management, but there was not a tillage effect on grain yield with moderate and high residue removal.

Therefore, when soil water deficits are not limiting to crop productivity, crop residue removal may result in increased yield and less immobilization of applied $\mathrm{N}$, while residue removal results in increased $\mathrm{N}$ removal. Research was conducted to determine the combined effect of these factors on crop yield and EONR for the following corn crop. The hypothesis was that the EONR for corn following corn when residue is removed, is less even though yield may be increased compared to no residue removal under irrigated, no-till conditions.

\section{MATERIALS AND METHODS}

Field research was conducted in 2013 and 2014, with continuous corn from 2012, at two locations of the Agricultural Research and Development Center (ARDC) and one of the Haskell Agricultural Laboratory (HAL) of the University of Nebraska-Lincoln. The sites were: ARDC south pivot (SP) at 41.182 N, 96.482 W, 360 m altitude with Yutan silty clay loam of 2 to $6 \%$ slope (mixed, superactive, mesic Mollic Hapludalf); ARDC north pivot (NP) at $41.150 \mathrm{~N}, 96.449 \mathrm{~W}, 355 \mathrm{~m}$ altitude with Tomek and Filbert silt loam soil of 0 to $2 \%$ slope

Table I. Analysis of variation for crop residue removal and $\mathrm{N}$ rate effects on the second and third year of continuous irrigated no-till corn at three locations in eastern Nebraska.

\begin{tabular}{|c|c|c|c|c|c|c|c|c|}
\hline Source of variation & $\mathrm{df}$ & NDVI† & NDRE & Grain yield & $\mathrm{N}$ uptake & $\mathrm{NHI}$ & RE & $\mathrm{AE}$ \\
\hline \multicolumn{9}{|c|}{ ARDC south pivot } \\
\hline Residue & I & $* * *$ & $* * *$ & $* *$ & ns $\ddagger$ & ns & ns & ns \\
\hline Yr $\times$ Residue & I & ns & ns & ns & & & & ns \\
\hline $\mathrm{N}$ & 5 & $* * *$ & $* * *$ & $* * *$ & $* *$ & ns & ns & ns \\
\hline Residue $\times \mathrm{N}$ & 5 & ns & ns & ns & ns & ns & ns & ns \\
\hline Yr $\times N$ & 5 & $* * *$ & ns & $* *$ & & & & ns \\
\hline Yr $\times$ Residue $\times N$ & 5 & $* *$ & $*$ & ns & & & & ns \\
\hline \multicolumn{9}{|c|}{ ARDC north pivot } \\
\hline Residue & I & $* * *$ & $* * *$ & $* *$ & $* *$ & ns & ns & ns \\
\hline Yr $\times$ Residue & I & ns & ns & ns & ns & ns & ns & ns \\
\hline $\mathrm{N}$ & 5 & $* * *$ & $* * *$ & $* * *$ & $* * *$ & ns & $*$ & ns \\
\hline Residue $\times \mathrm{N}$ & 5 & ns & ns & ns & ns & ns & ns & ns \\
\hline $\mathrm{Y} \times \mathrm{N}$ & 5 & $* * *$ & ns & $* *$ & ns & $* *$ & ns & ns \\
\hline $\mathrm{Y} \times$ Residue $\times \mathrm{N}$ & 5 & $* *$ & $*$ & ns & ns & ns & ns & ns \\
\hline \multicolumn{9}{|c|}{ Haskell Agricultural Laboratory } \\
\hline Residue & I & ns & ns & **** & $* * *$ & ns & ns & ns \\
\hline Yr $\times$ Residue & I & $* *$ & $* * *$ & $* *$ & $* * *$ & ns & ns & ns \\
\hline $\mathrm{N}$ & 5 & $* * *$ & $* * *$ & $* *$ & $* * *$ & ns & ns & ns \\
\hline Residue $\times \mathrm{N}$ & 5 & $* *$ & * & ns & ns & ns & ns & ns \\
\hline $\mathrm{Yr} \times \mathrm{N}$ & 5 & ns & ns & ns & ns & ns & ns & ns \\
\hline Yr $\times$ Residue $\times N$ & 5 & ns & $*$ & ns & ns & ns & ns & ns \\
\hline \multicolumn{9}{|l|}{$* P<0.05$} \\
\hline \multicolumn{9}{|l|}{$* * P<0.0 \mathrm{I}$} \\
\hline \multicolumn{9}{|l|}{$* * * P<0.001$} \\
\hline \multicolumn{9}{|c|}{$\begin{array}{l}\text { † NDVI, normalized difference vegetative index; NDRE, normalized difference red edge; NHI, nitrogen harvest index; RE, nitrogen recovery ef- } \\
\text { ficiency; and } \mathrm{AE} \text {, nitrogen agronomic efficiency. Sources of variation involving } \mathrm{N} \text { rate had } 4 \text { rather than } 5 \mathrm{df} \text { for RE and } \mathrm{AE} \text {. }\end{array}$} \\
\hline
\end{tabular}


(fine, smectitic, mesic Pachic Argiudoll and fine, smectitic, mesic Vertic Argialboll, respectively); and HAL under lateral move sprinkler irrigation at $42.389 \mathrm{~N}, 96.958 \mathrm{~W}, 445 \mathrm{~m}$ altitude with Moody silt loam of 6 to $11 \%$ slope (fine-silty, mixed mesic Udic Haplustoll). Soil organic matter by loss on ignition and $\mathrm{pH}$ 1:1 water were respectively: $31.5 \mathrm{mg} \mathrm{kg}^{-1}$ and 5.9 for SP; $37.0 \mathrm{mg} \mathrm{kg}^{-1}$ and 6.4 for NP; and $30.7 \mathrm{mg} \mathrm{kg}^{-1}$ and 7.3 for HAL. The ARDC and HAL sites were irrigated with center pivot and a lateral move sprinkler systems, respectively. All sites were no-till managed. The previous crop was corn.

The experimental plots were maintained over the $2 \mathrm{yr}$. The trials had a split plot design with four replications. The main plot treatments were 0 and $>75 \%$ residue removal in the fall for the ARDC fields and in the spring for HAL trials. The residue removal treatments were applied to the residue of the previous (2012) crop and after harvest of the first (2013) experimental crop. The subplot treatments were six $\mathrm{N}$ rates of 0 to $250 \mathrm{~kg} \mathrm{ha}^{-1}$ at ARDC and 0 to $200 \mathrm{~kg} \mathrm{ha}^{-1}$ at HAL. Fertilizer N was broadcast applied as ammonium nitrate 34-0-0 without incorporation in the spring before planting. Fertilizer was applied with a tractor mounted drop applicator or with man held applicators for application of weighed amounts. Subplot size was 6 by $12 \mathrm{~m}$.
The corn hybrid was Pioneer 1151AM at ARDC. The HAL hybrids were Channel Bio 209-85VT3 PRIB in 2013 and Renze 5X288HXT/LL in 2014. These had triple stack root worm, corn borer and glyphosate resistance. The seeding rate was 80,000 to 84,000 seed ha $\mathrm{ha}^{-1}$ at ARDC and $79,000 \mathrm{seed} \mathrm{ha}^{-1}$ at HAL in $75 \mathrm{~cm}$ rows. Planting dates were: 13 May 2013 for SP. and NP; 22 Apr. 2014 for SP; 24 Apr. 2014 for NP; and 2 June 2013 and 22 May 2014 for HAL. No fertilizer other than $\mathrm{N}$ was applied consistent with (Shapiro et al., 2009) except for ARDC SP. where $20 \mathrm{~kg} \mathrm{ha}^{-1} \mathrm{P}$ was broadcast applied each year as triple super phosphate.

Observations included canopy reflection at V9-10 for normalized difference red edge (NDRE; NDRE $=(780 \mathrm{~nm}-$ $730 \mathrm{~nm}) /(780 \mathrm{~nm}+730 \mathrm{~nm}))$ and normalized difference vegetative index (NDVI; NDVI $=(780 \mathrm{~nm}-670 \mathrm{~nm}) /(780 \mathrm{~nm}+$ $670 \mathrm{~nm}$ )) with a hand carried Rapid Scan (Holland Scientific, Lincoln, NE). After physiological maturity, six plants were sampled, and residue (aboveground biomass excluding the ears) and grain dry weights were determined. Residue and grain samples were analyzed for $\mathrm{N}$ content, either by using a Flash 2000 Organic Elemental Analyzer CN analyzer or by LECO combustion (Gavlak et al., 2005). The harvest area for yield

Table 2. Crop residue removal and $\mathrm{N}$ rate effects on normalized difference vegetative index (NDVI) and normalized difference red edge (NDRE) at V9-10 for 6 site-years in eastern Nebraska.

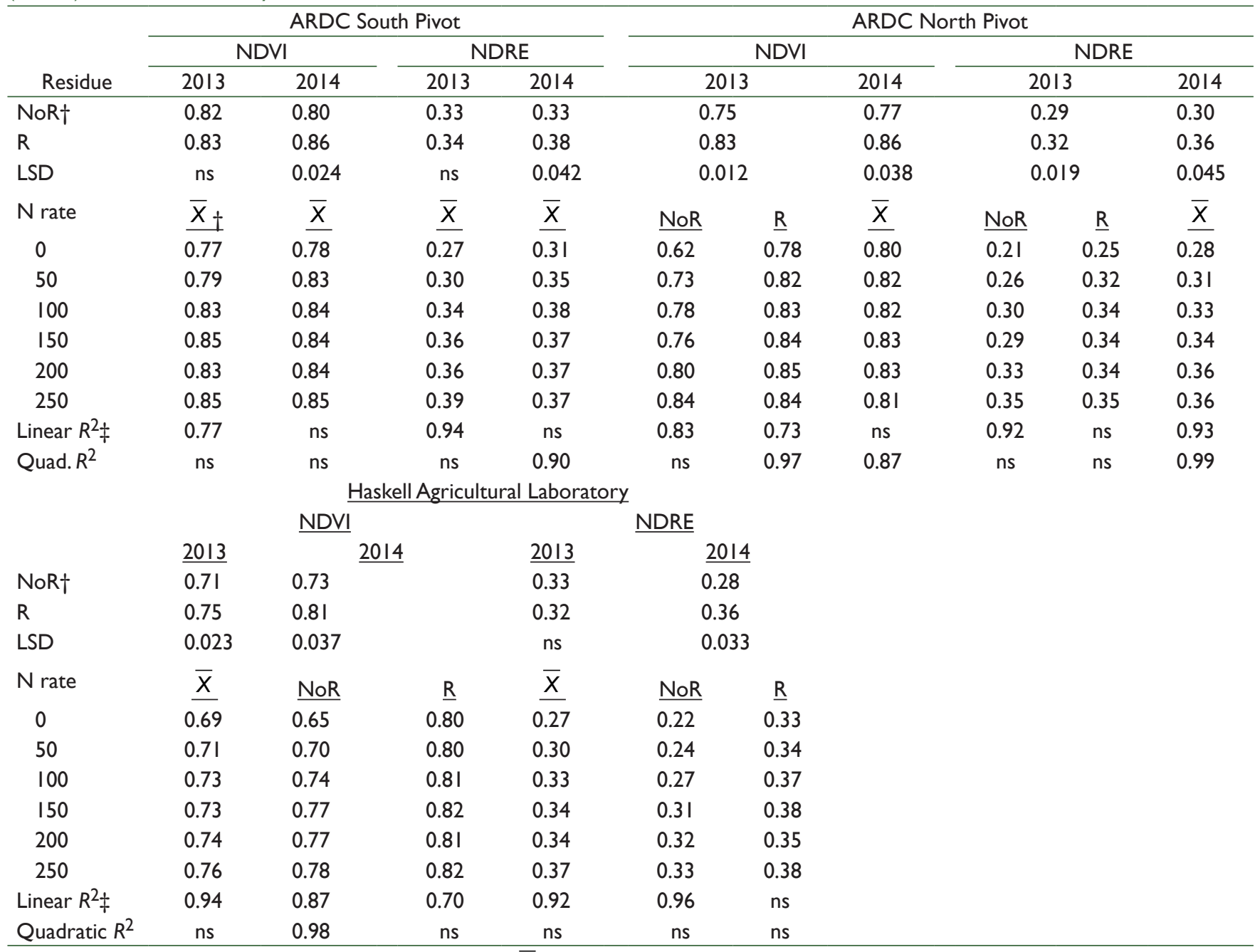

$\dagger$ NoR and R: no removal and $>75 \%$ removal of corn residue. $\bar{X}$ indicates the mean of NoR and $R$ in cases of no residue removal $\times \mathrm{N}$ rate interaction. LSD is least significant difference at 0.05 .

$\ddagger R^{2}$ values are for regression on treatment means. 
Table 3. Crop residue removal and $\mathrm{N}$ rate effects on aboveground biomass $\mathrm{N}$ content $\left(\mathrm{NUp}, \mathrm{kg} \mathrm{ha}^{-1}\right.$ ), nitrogen harvest index $\left(\mathrm{NHI}, \mathrm{kg} \mathrm{kg}^{-1}\right)$, and applied $\mathrm{N}$ efficiency of recovery (RE, $\mathrm{kg} \mathrm{kg}^{-1}$ ) and agronomic use (AE, $\left.\mathrm{kg} \mathrm{kg}^{-1}\right)$ for 6 site-years in eastern Nebraska. The residue removal by $\mathrm{N}$ rate interactions were not significant.

\begin{tabular}{|c|c|c|c|c|c|c|c|c|c|c|c|c|}
\hline \multirow[b]{3}{*}{ Residue } & \multicolumn{8}{|c|}{ ARDC North Pivot } & \multirow{2}{*}{\multicolumn{4}{|c|}{$\frac{\text { ARDC South Pivot }}{2014}$}} \\
\hline & \multicolumn{4}{|c|}{2013} & \multicolumn{4}{|c|}{2014} & & & & \\
\hline & NUp & $\mathrm{NHI}$ & RE & $\mathrm{AE}$ & $\mathrm{NU}$ & $\mathrm{NHI}$ & $\mathrm{RE}$ & $\mathrm{AE}$ & $\mathrm{NUp}$ & $\mathrm{NHI}$ & RE & $\mathrm{AE}$ \\
\hline NoRt & 228 & 0.68 & 0.27 & 13.7 & 170 & 0.56 & 0.32 & 14.0 & 158 & 0.60 & 0.30 & 14.0 \\
\hline $\mathrm{R}$ & 264 & 0.66 & 0.47 & 4.8 & 220 & 0.53 & 0.37 & 29.3 & 199 & 0.58 & 0.48 & 25.1 \\
\hline LSD 0.05 & 21.1 & ns & ns & ns & 49.9 & ns & ns & ns & 20.6 & ns & ns & ns \\
\hline \multicolumn{13}{|l|}{$\mathrm{N}, \mathrm{kg} \mathrm{ha} \mathrm{h}^{-1}$} \\
\hline 0 & 204 & 0.71 & & & 154 & 0.50 & & & 138 & 0.55 & & \\
\hline 50 & 231 & 0.68 & 0.53 & 16.1 & 178 & 0.50 & 0.47 & 17.2 & 164 & 0.54 & 0.52 & 17.2 \\
\hline 100 & 248 & 0.67 & 0.43 & 7.8 & 181 & 0.54 & 0.26 & 24.2 & 175 & 0.57 & 0.37 & 13.6 \\
\hline 150 & 255 & 0.70 & 0.33 & 8.7 & 212 & 0.54 & 0.37 & 23.9 & 195 & 0.59 & 0.25 & 23.9 \\
\hline 200 & 253 & 0.66 & 0.24 & 7.6 & 215 & 0.59 & 0.30 & 21.4 & 192 & 0.66 & 0.27 & 21.4 \\
\hline 250 & 284 & 0.60 & 0.32 & 6.2 & 231 & 0.60 & 0.31 & 21.5 & 208 & 0.65 & 0.54 & 21.5 \\
\hline \multirow[t]{4}{*}{ LSD } & 40.2 & 0.069 & ns & ns & 40.4 & ns & ns & ns & 28.7 & 0.079 & ns & ns \\
\hline & \multicolumn{8}{|c|}{ Haskell Agricultural Laboratory } & & & & \\
\hline & \multicolumn{4}{|c|}{$\underline{2013}$} & \multicolumn{4}{|c|}{$\underline{2014}$} & & & & \\
\hline & $\underline{N U_{p}}$ & $\underline{\mathrm{NHI}}$ & $\underline{\mathrm{RE}}$ & $\underline{\mathrm{AE}}$ & $\underline{N} U_{p}$ & $\underline{\mathrm{NHI}}$ & $\underline{\mathrm{RE}}$ & $\underline{\mathrm{AE}}$ & & & & \\
\hline NoRt & 153 & 0.66 & 0.20 & 11.2 & 89 & 0.69 & 0.16 & 11.5 & & & & \\
\hline$R$ & 158 & 0.70 & 0.09 & 10.9 & 149 & 0.68 & 0.44 & 14.3 & & & & \\
\hline LSD & ns & ns & ns & ns & 16.1 & ns & ns & ns & & & & \\
\hline \multicolumn{13}{|l|}{$\mathrm{N}, \mathrm{kg} \mathrm{ha}{ }^{-\mathrm{I}}$} \\
\hline 0 & 139 & 0.68 & & & 89 & 0.69 & & & & & & \\
\hline 40 & 140 & 0.70 & 0.03 & 14.6 & 100 & 0.70 & 0.27 & 11.9 & & & & \\
\hline 80 & 152 & 0.68 & 0.16 & 11.0 & 115 & 0.68 & 0.32 & 12.3 & & & & \\
\hline 120 & 165 & 0.70 & 0.22 & 16.3 & 133 & 0.68 & 0.37 & 16.4 & & & & \\
\hline 160 & 165 & 0.65 & 0.16 & 5.7 & 143 & 0.70 & 0.34 & 15.8 & & & & \\
\hline 200 & 170 & 0.67 & 0.16 & 7.9 & 133 & 0.66 & 0.22 & 8.2 & & & & \\
\hline LSD & 13.0 & ns & ns & ns & 35.0 & ns & ns & ns & & & & \\
\hline Linear $R^{2} \ddagger$ & 0.90 & ns & ns & ns & 0.82 & ns & ns & ns & & & & \\
\hline Quadratic $R^{2}$ & ns & ns & ns & ns & ns & ns & ns & ns & & & & \\
\hline
\end{tabular}

$\dagger$ NoR and $R$ : no removal and $>75 \%$ removal of corn residue. LSD is least significant difference at 0.05 .

$\ddagger R^{2}$ values are for regression on treatment means.

Table 4. Crop residue removal and $\mathrm{N}$ rate effects on residual soil nitrate $\mathrm{N}\left(\mathrm{mg} \mathrm{kg}^{-1}\right)$ levels following harvest for the 0 - to 30 - $\mathrm{cm}$ and 30 to $120-\mathrm{cm}$ depths at two locations in eastern Nebraska. The residue removal by $\mathrm{N}$ rate interactions were not significant.

\begin{tabular}{|c|c|c|c|c|c|c|c|c|}
\hline \multirow[b]{3}{*}{ Residue } & \multicolumn{4}{|c|}{ ARDC South Pivot } & \multicolumn{4}{|c|}{ ARDC North Pivot } \\
\hline & \multicolumn{2}{|c|}{2013} & \multicolumn{2}{|c|}{2014} & \multicolumn{2}{|c|}{2013} & \multicolumn{2}{|c|}{2014} \\
\hline & $0-30$ & $30-120$ & $0-30$ & $30-120$ & $0-30$ & $30-120$ & $0-30$ & $30-120$ \\
\hline NoRt & 3.28 & 1.55 & 2.89 & 2.04 & 6.06 & 4.25 & 3.51 & 1.80 \\
\hline Removed & 4.04 & 1.79 & 3.24 & 2.55 & 6.28 & 4.66 & 2.66 & 1.67 \\
\hline LSD & 0.703 & nsł & ns & ns & ns & ns & 0.812 & ns \\
\hline \multicolumn{9}{|c|}{$\mathrm{N}$ rate, $\mathrm{kg} \mathrm{ha}^{-1}$} \\
\hline 0 & 2.89 & 1.08 & 2.46 & 1.74 & 3.68 & 2.01 & 2.46 & 1.74 \\
\hline 50 & 3.50 & 1.16 & 2.62 & 1.48 & 4.78 & 2.60 & 2.62 & 1.48 \\
\hline 100 & 3.93 & 0.81 & 3.20 & 2.09 & 4.93 & 2.34 & 3.20 & 2.09 \\
\hline 150 & 3.00 & 1.53 & 3.32 & 2.73 & 5.69 & 4.62 & 3.32 & 2.73 \\
\hline 200 & 4.26 & 1.82 & 3.21 & 2.33 & 9.68 & 8.00 & 3.21 & 2.33 \\
\hline 250 & 4.38 & 3.61 & 3.59 & 3.38 & 8.28 & 7.15 & 3.59 & 3.38 \\
\hline Linear $R^{2} \S$ & ns & 0.57 & ns & ns & 0.72 & 0.78 & ns & ns \\
\hline Quadratic $R^{2}$ & ns & 0.90 & ns & ns & ns & ns & ns & ns \\
\hline
\end{tabular}

$\dagger$ NoR and Removed: no removal and $>75 \%$ removal of corn residue. LSD is least significant difference at 0.05 .

$\ddagger \mathrm{ns}$, not significant.

$\S R^{2}$ values are for regression on treatment means. 
determination was 1.5 by $6 \mathrm{~m}$ and harvested either by hand harvest of ears and subsequent shelling or with a plot combine. Nitrogen uptake (NUp) or the N content of the aboveground biomass, $\mathrm{N}$ harvest index, nitrogen recovery efficiency (NRE), and nitrogen agronomic efficiency (NAE) were calculated with: $\mathrm{NRE}=$ (the difference of NUp with and without $\mathrm{N}$ applied) $/ \mathrm{N}$ rate $\left(\mathrm{kg} \mathrm{kg}^{-1}\right)$; and $\mathrm{NAE}=$ (the difference of grain yield with and without $\mathrm{N}$ applied)/ $\mathrm{N}$ rate $\left(\mathrm{kg} \mathrm{kg}^{-1}\right)$. These $\mathrm{N}$ traits were not determined for SP in 2013 due to loss of grain samples. Soil was sampled with two cores per sample in $30-\mathrm{cm}$ increments to 120 -cm depth to determine residual soil $\mathrm{NO}_{3}{ }^{-}-\mathrm{N}$ for the ARDC site-seasons.

Data analyses was done with Statistix 10.0 (Analytical Software, Tallahassee, FL). Analysis of variance was by siteyear for all variables except for grain yield which was by sites combined over years. Years were considered fixed effects as the first and second year of corn following corn with residue removal treatments. Treatment effects were considered significant at $\mathrm{a}=0.05$. Linear and nonlinear regression analyses on plot values related grain yield to $\mathrm{N}$ rate. The EONRs were determined for ratios of $\mathrm{N}$ use costs relative to grain value $\left[\left(\mathrm{US}_{\mathrm{kg}}-1\right)\left(\$ \mathrm{~kg}^{-1}\right)^{-1}\right]$ of $5,8,11$, and 14 .

\section{RESULTS}

The residue removal $\times \mathrm{N}$ rate $\times$ year interaction was significant for NDRE and NDVI at V9-10 for all locations except for NDVI at HAL (Table 1). The interactions were due to a greater response to applied $\mathrm{N}$ with no residue removal compared with removal and with generally greater response in 2014 compared with 2013 (Table 2). The residue removal $\times$ year interaction was significant at HAL due to greater residue removal effects in 2014 compared with 2013. Values for NDRE and NDVI were higher with $\mathrm{N}$ applied compared with no $\mathrm{N}$ applied except for NDRE with residue removal at NP in 2013 and HAL in 2014, and for NDVI at SP in 2014.

Mean NUp was $181 \mathrm{~kg} \mathrm{ha}^{-1}$ and mean NHI was 0.63 . The residue removal $\times \mathrm{N}$ rate interaction did not affect $\mathrm{NUp}$ and NHI (Tables 1 and 3). Mean NUp was 22\% greater with residue removal compared with no removal and greater for all site-years except HAL in 2013. The residue removal $\times$ year interaction affected NUp at HAL because of a greater residue removal effect in 2014 compared with 2013. Uptake of $\mathrm{N}$ was increased with $\mathrm{N}$ application. Residue removal did not affect NHI, and NHI was inconsistently affected by $\mathrm{N}$ rate at SP and NP in 2013. Mean NRE and NAE were 0.31 and $14.9 \mathrm{~kg} \mathrm{~kg}^{-1}$, respectively (Table 3). Treatment effects on NRE and NAE were not significant except for a decline in NRE with increasing $\mathrm{N}$ rate for NP. However, mean NRE was $43 \%$ greater with residue removal compared with no removal and in all cases except for HAL in 2013 where NRE was very low due to relatively low crop response to applied N. There was no such trend for residue removal effects on NAE. The effect of crop residue removal on residual soil $\mathrm{NO}_{3}{ }^{-1}-\mathrm{N}$ following harvest was inconsistent at the 0 - to $30-\mathrm{cm}$ depth with no effect at the 30to 120 -cm depth (Table 4).

Grain yield averaged $10 \mathrm{Mg} \mathrm{ha}^{-1}$ (Fig. 1). Yield was not affected by the residue removal $\times \mathrm{N}$ rate $\times$ year interaction (Table 1). Mean grain yield was greater at all locations with residue removal compared with no removal and the residual removal effect was greater at HAL in 2014 compared with 2013. The residue removal effect on grain yield for SP was significant in the combined ANOVA but not with the individual site-year ANOVAs. The effect of $100 \mathrm{~kg} \mathrm{ha}^{-1} \mathrm{~N}$ on yield was greater with residue removal compared to no removal in 2014 at $\mathrm{SP}$ and NP accounting for the significant $\mathrm{N} \times$ year interactions. The average yield increase due to residue removal was $20 \%$, with site-year mean increases of 2.7 to $71 \%$. Mean grain yield increase due to $\mathrm{N}$ application was $3.42 \mathrm{Mg} \mathrm{ha}^{-1}$ and siteyear yield increases ranged from 11 to $72 \%$. Responses included linear and curvilinear responses although the yield peak was often not reached.

The EONR could not be estimated for some situations because of linear effects of $\mathrm{N}$ rate on grain yield or failure to reach peak yield at the upper $\mathrm{N}$ rate in several cases (Table 5). With past research for high yield irrigated corn in Nebraska, mean EONR ranged from 141 to $180 \mathrm{~kg} \mathrm{ha}^{-1}$ for corn after corn with cost/price ratios ranging from 13 to $5 \mathrm{~kg} \mathrm{~kg}^{-1}$ (Dobermann et al., 2011). With EONR set at an upper limit $200 \mathrm{~kg} \mathrm{ha}^{-1}$ in cases where EONR could not be estimated or was greater than this limit, then EONR is 8 to $24 \mathrm{~kg} \mathrm{ha}^{-1}$ with a mean of $18 \mathrm{~kg} \mathrm{ha}^{-1}$ less with residue removal compared with no removal.

\section{DISCUSSION}

The results indicate that immobilization of applied $\mathrm{N}$ was reduced by corn residue removal. More $\mathrm{N}$ mineralization associated with higher soil temperature may have contributed to greater NUp with residue removal. The NDRE and NDVI measures at V9-10 with residue removal indicate increased early NUp as these measures are sensitive to leaf color, and therefore leaf $\mathrm{N}$ concentration, and leaf area index. More NUp and greater NRE indicate improved $\mathrm{N}$ availability throughout the season with residue removal compared with no removal.

The $20 \%$ yield increases due to crop residue removal were greater than the average of $3 \%$ increase determined from Karlen et al. (2014). Much of this yield increase was due to 2014 results at two sites indicating greater residue removal effect on yield for the third compared with the second year of continuous corn (Fig. 1). The greater effects on yield in this study may be attributed to lack of soil water deficits with irrigation while in many non-irrigated studies, deficits with residue removal compared to no removal may have caused more yield reduction (Linden et al., 2000; Wilhelm et al., 2004; Varvel et al., 2008).

Grain yield response to $\mathrm{N}$ rate often did not reach a peak. The mean maximum grain yield response to $\mathrm{N}$ rate was a $49 \%$ increase. In comparison, the mean increase was $66 \%$ in another study of 11 corn after corn site-years for high yield corn (Dobermann et al., 2011). Some of this difference was due to higher maximum $\mathrm{N}$ rates in the latter study. While NRE was higher with residue removal compared with no removal, the average was only 0.31 averaged across all $\mathrm{N}$ rate application rates. In contrast, the average NRE at EONR for corn after corn in the above cited study of 11 site-years was 0.67 (Wortmann et al., 2011). Therefore, the results indicate relatively poor $\mathrm{N}$ recovery and yield response in the current study. These two studies differed for two management practices including split application of $\mathrm{N}$ and tillage for most corn after corn site-years in the Dobermann et al. (2011) study, while all $\mathrm{N}$ was applied pre-plant and all site-years were no-till in the 
Table 5. Crop residual removal effects on economically optimal nitrogen rates (EONR) $\left(\mathrm{kg} \mathrm{N} \mathrm{ha}^{-1}\right)$ at four $\mathrm{N}$ use costs to grain value ratios $\left[\left(U S \$ \mathrm{~kg}^{-1} \mathrm{~N}\right)\left(\$ \mathrm{~kg}^{-1} \text { corn grain }\right)^{-1}\right]$.

\begin{tabular}{|c|c|c|c|c|}
\hline \multirow[b]{2}{*}{ Site-year } & \multicolumn{4}{|c|}{ Fertilizer $\mathrm{N}$ use cost to corn grain value ratio } \\
\hline & 5 & 8 & II & 14 \\
\hline SPI3 R & - & - & - & - \\
\hline SPI3 NoR & - & - & 177 & 102 \\
\hline NPI3 R & 123 & 73 & 23 & 0 \\
\hline NPI 3 NoR & 177 & 127 & 77 & 27 \\
\hline HALI 3 R & 165 & 115 & 65 & 15 \\
\hline HALI 3 NoR & 95 & 65 & 35 & 5 \\
\hline SPI4 R & 194 & 178 & 161 & 145 \\
\hline SPI4 NoR & - & - & - & - \\
\hline NPI4 R & 227 & 212 & 197 & 182 \\
\hline NPI 4 NoR & - & - & - & - \\
\hline HALI4 R & 139 & 117 & 96 & 74 \\
\hline \multirow[t]{2}{*}{ HALI 4 NoR } & - & - & - & 218 \\
\hline & \multicolumn{4}{|c|}{ Mean EONR for EONR $\leq 200 \mathrm{~kg} \mathrm{~N} \mathrm{ha-l}$} \\
\hline NoRt & 179 & 165 & 148 & 122 \\
\hline $\mathrm{R}$ & 170 & 147 & 124 & 103 \\
\hline Difference & 9 & 18 & 25 & 20 \\
\hline
\end{tabular}

$\dagger$ NoR and R: no removal and $>75 \%$ removal of corn residue, respectively.

current study. Residual soil nitrate following harvest to $1.2-\mathrm{m}$ depth was low and not affected much by $\mathrm{N}$ application rates except for NP in 2013. The low NRE coupled with generally low residual soil nitrate indicate considerable $\mathrm{N}$ loss.

An implication of a lack of plateau or peak in grain yield response to $\mathrm{N}$ rate was failure to determine EONR for several site-years. However, EONR could be determined twice as often with residue removal compared to no removal (Table 4) suggesting lower EONR with removal. The effect was not consistent or great, however, as the mean difference with EONR capped at $200 \mathrm{~kg} \mathrm{ha}^{-1}$ was only $18 \mathrm{~kg} \mathrm{ha}^{-1} \mathrm{~N}$. This is very similar to $13 \mathrm{~kg} \mathrm{ha}^{-1}$ reduction in EONR with residue removal determined by Sindelar et al. (2013). Higher corn yield with lower $\mathrm{N}$ rates associated with residue removal may not be sustainable in the long term due to total soil $\mathrm{N}$ decline (Halvorson and Stewart, 2015).

\section{CONCLUSION}

Significant grain yield increase can be expected for irrigated no-till corn following corn if some crop residue is removed. While fertilizer $\mathrm{N}$ recovery and crop $\mathrm{N}$ uptake are likely to be greater with residue removal, there is little justification to adjust pre-plant $\mathrm{N}$ rate due to low predictability of the residue removal effect on applied $\mathrm{N}$ need. With lower levels of removal, the effect on EONR is likely to be even less than in this study. To capitalize on the potential to reduce applied $\mathrm{N}$ in cases of residue removal, canopy sensor guided in-season $\mathrm{N}$ application may be needed as $\mathrm{N}$ is then applied according to canopy reflectance. This research did not address the long-term effect of

Fig. I. Corn grain yield response to applied N, with and without residue removal, for three locations in eastern Nebraska including ARDC South Pivot, ARDC North Pivot, and Haskell Agricultural Laboratory. Residue removal by $\mathrm{N}$ rate interaction effects were not significant. Regression was on $\mathrm{N}$ rate means but $R^{2}$ values are for adjusted $R^{2}$ with regression analysis on plot values.

a
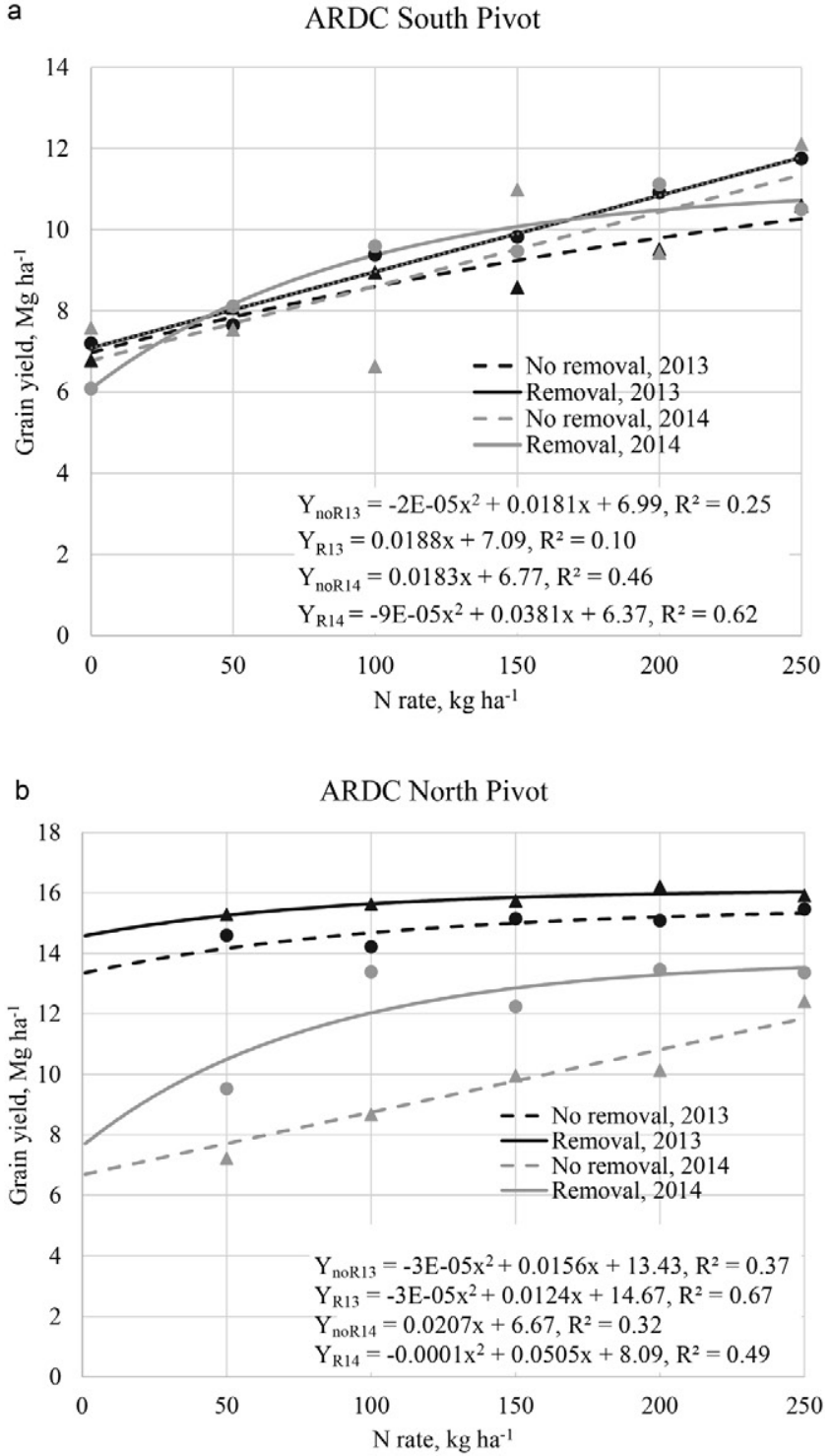

c

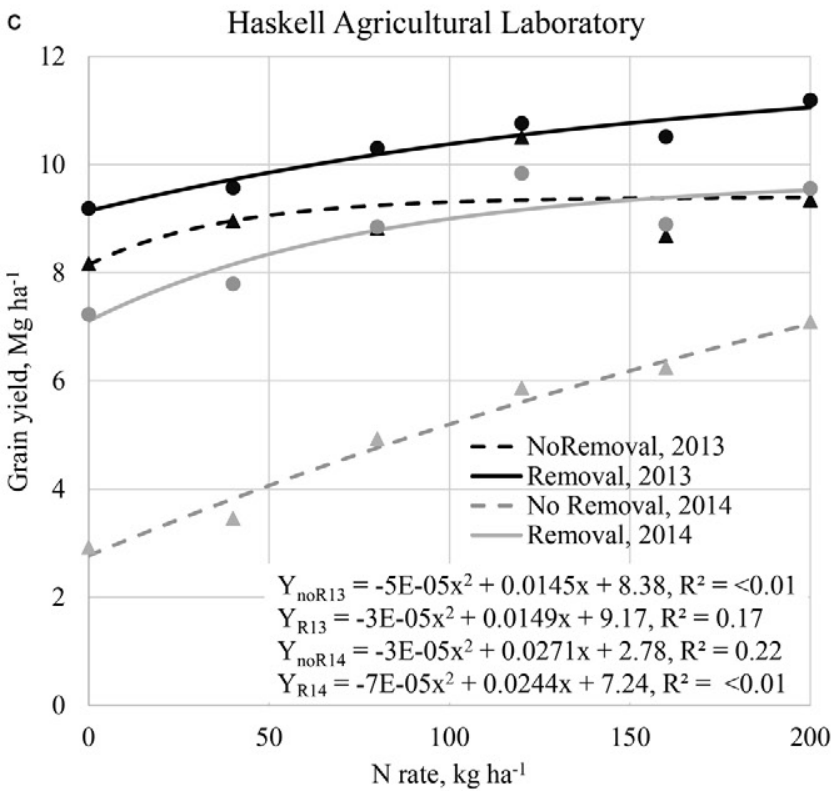


many years of continuous residue removal but levels of residue removal are likely to be less than in this study if done continuously to maintain soil organic matter levels.

\section{ACKNOWLEDGMENTS}

We acknowledge the contributions of technologist Michael Mainz and farm managers Greg Teichmeier and Keith Stewart to this research.

\section{REFERENCES}

Alternative Fuels Data Center. 2014. Ethanol feedstocks. U.S. Department of Energy: Energy Efficiency and Renewable Energy. http:// www.afdc.energy.gov/fuels/ethanol_feedstocks.html (accessed 21 May 2015).

Biomass Research and Development Board. 2009. Increasing feedstock production for biofuels: Economic drivers, environmental implications, and the role of research. Biomass Research and Development Board. http://www.esd.ornl.gov/eess/8_Increasing_Biofuels_ Feedstock_Production.pdf(accessed 21 May 2015).

Cantrell, K.B., J.M. Novak, J.R. Frederick, D.L. Karlen, and D.W. Watts. 2014. Influence of corn residue harvest management on grain, stover, and energy yields. BioEnergy Res. 7:590-597. doi:10.1007/s12155-014-9433-9

Coulter, J.A., and E.D. Nafziger. 2008. Continuous corn response to residue management and nitrogen fertilization. Agron. J. 100:1774-1780. doi:10.2134/agronj2008.0170

Dobermann, A., C.S. Wortmann, R.B. Ferguson, G.W. Hergert, C.A. Shapiro, D.D. Tarkalson, and D. Walters. 2011. Nitrogen response and economics for irrigated corn in Nebraska. Agron. J. 103:67-75. doi:10.2134/agronj2010.0179

DuPont Cellulosic Ethanol. 2012. DuPont corn stover harvest program. http://biofuels.dupont.com/cellulosic-ethanol/nevada-site-cefacility/corn-stover-harvest-program/ (accessed 21 May 2015).

Gavlak, R.G., D.A. Horneck, and R.O. Miller. 2005. Total nitrogen in botanical materials- automated combustion method. In: Soil, plant and water reference methods for the western region. 3 rd ed. North Am. Proficiency Testing Program. http://www.naptprogram.org/files/napt/western-states-method-manual-2005.pdf (accessed 7 Nov. 2015). p. 153-154.

Halvorson, A.D., and C.E. Stewart. 2015. Stover removal affects notill irrigated corn yields, soil carbon, and nitrogen. Agron. J. 107:1504-1512. doi:10.2134/agronj15.0074

Karlen, D.L., S.J. Birrell, J.M.F. Johnson, S.L. Osborne, T.E. Schumacher, G.E. Varvel et al. 2014. Multilocation corn stover harvest effects on crop yields and nutrient removal. BioEnergy Res. 7:528-539. doi:10.1007/s12155-014-9419-7

Klopfenstein, T.J., G.E. Erickson, and L.L. Berger. 2013. Maize is a critically important source of food, feed, energy and forage in the USA. Field Crops Res. 153:5-11. doi:10.1016/j.fcr.2012.11.006
Linden, D.R., C.E. Clapp, and R.H. Dowdy. 2000. Long-term corn grain and stover yields as a function of tillage and residue removal in east central Minnesota. Soil Tillage Res. 56:167-174. doi:10.1016/S0167-1987(00)00139-2

Myrold, D.D., and P.J. Bottomley. 2008. Nitrogen mineralization and immobilization. In: J.S. Schepers and W.R. Raun, editors, Nitrogen in agricultural systems. Agron. Monogr. 49. ASA, CSSA, and SSSA, Madison, WI. p. 157-172.

Salvagiotti, F., A. Weiss, A. Dobermann, D.T. Walters, K.G. Cassman, and J.E. Specht. 2008. Nitrogen uptake, fixation and response to fertilizer N in soybeans: A review. Field Crops Res. 108:1-13. doi:10.1016/j.fcr.2008.03.001

Schmer, M.R., G.E. Varvel, R.F. Follett, V.L. Jin, and B.J. Wienhold. 2014. Tillage and residue management effects on soil carbon and nitrogen under irrigated continuous corn. Soil Sci. Soc. Am. J. 78:1987-1996. doi:10.2136/sssaj2014.04.0166

Schoessow, K.A., K.C. Killian, and L.G. Bundy. 2010. Soybean residue management and tillage effects on corn yields and response to applied nitrogen. Agron. J. 102:1186-1193. doi:10.2134/ agronj2010.0033

Shapiro, C.S., R.B. Ferguson, G.W. Hergert, C.S. Wortmann, and D.T. Walters. 2009. Fertilizer suggestions for corn. EC117. Univ. of Nebraska-Lincoln Ext., Lincoln.

Sims, A.L., J.S. Schepers, R.A. Olson, and J.F. Power. 1998. Irrigated corn yield and nitrogen accumulation response in a comparison of no-till and conventional till: Tillage and surface-residue variables. Agron. J. 90:630-637. doi:10.2134/agronj1998.00021962 $009000050011 \mathrm{x}$

Sindelar, A.J., J.A. Coulter, J.A. Lamb, and J.A. Vetsch. 2013. Agronomic responses of continuous corn to stover, tillage, and nitrogen management. Agron. J. 105:1498-1506. doi:10.2134/ agronj2013.0181

Varvel, G.E., K.P. Vogel, R.B. Mitchell, R.F. Follett, and J.M. Kimble. 2008. Comparison of corn and switchgrass on marginal soils for bioenergy. Biomass Bioenergy 32:18-21. doi:10.1016/j. biombioe.2007.07.003

Wilhelm, W.W., J.M.F. Johnson, J.L. Hatfield, W.B. Voorhees, and D.R. Linden. 2004. Crop and soil productivity response to corn residue removal: A literature review. Agron. J. 96:1-17. doi:10.2134/agronj2004.0001

Wortmann, C.S., R.N. Klein, and C.A. Shapiro. 2012. Harvesting crop residues. NebGuide G1846 revised. Univ. of Nebraska-Lincoln Ext., Lincoln.

Wortmann, C.S., D.D. Tarkalson, C.A. Shapiro, A.R. Dobermann, R.B. Ferguson, G.W. Hergert, and D. Walters. 2011. Nitrogen use efficiency for three cropping systems in Nebraska. Agron. J. 103:76-84. doi:10.2134/agronj2010.0189 